\title{
PRACTICAL TRAINING OF PERSONAL OF REGULAR SUBDIVISIONS OF STRUCTURAL UNITS OF OPERATIVE AND RESCUE SERVICE OF CIVIL PROTECTION OF UKRAINE
}

\author{
PhD in Pedagogical Sciences, Docent Pokaliuk V. M. \\ Cherkasy Institute of Fire Safety named after Chornobyl Heroes of National University of Civil \\ Defence of Ukraine, \\ Ukraine, Cherkasy
}

DOI: https://doi.org/10.31435/rsglobal_ws/31032020/6988

\section{ARTICLE INFO}

Received: 23 January 2020

Accepted: 15 March 2020

Published: 31 March 2020

\section{KEYWORDS}

Training,

Operative and Rescue Service of

Civil Protection of Ukraine,

practical classes,

tactical and drill classes,

tactical and special training,

regular guard,

personnel.

\begin{abstract}
The article describes the contents of the concepts of independent training and official training of the personnel of the units of the Operative and Rescue Service of Civil Protection of Ukraine, describes the practical component of their professional training directly in the units. It is established that the main types of occupations in the system of official training are lectures, seminars, practical classes, tactical-special trainings, control and testing classes. Types of practical training of rescuers are characterized: practical workout of training exercises (exercises and standards on special physical training), working out and correction of documents of operative response (plans, cards), operative-tactical study of service area and objects, solving tactical tasks, night test tactical tasks training, fire and emergency management, tactical training.

At the same time, there is a contradiction between the increased level of requirements for the preparedness of rescuers in modern conditions and the traditional system of their professional training, which does not take into account changes in the extension and complication of professional tasks.
\end{abstract}

Citation: Pokaliuk V. M. (2020) Practical Training of Personal of Regular Subdivisions of Structural Units of Operative and Rescue Service of Civil Protection of Ukraine. World Science. 3(55), Vol.3. doi: 10.31435/rsglobal_ws/31032020/6988

Copyright: (C) 2020 Pokaliuk V. M. This is an open-access article distributed under the terms of the Creative Commons Attribution License (CC BY). The use, distribution or reproduction in other forums is permitted, provided the original author(s) or licensor are credited and that the original publication in this journal is cited, in accordance with accepted academic practice. No use, distribution or reproduction is permitted which does not comply with these terms.

Introduction. According to the State Emergency Service of Ukraine (SES of Ukraine), 78,608 fires occurred in the country during 2018. The number of people killed in the fires was 1956, and 1515 were injured. Material losses from fires amounted to 8 billion 279 million 120 thousand UAH (of which direct material losses amounted to 2 billion 198 million 358 thousand UAH, and indirect losses - 6 billion 80 million 761 thousand UAH). On average, 215 fires occurred daily, killing 5 and injuring 4 people; 70 buildings and 13 pieces of equipment were destroyed or damaged by fire; daily material losses from the fires amounted to 22.7 million UAH [1].

In 2018, there were 128 emergencies in the territory of Ukraine: 48 of technogenic nature, 77 - natural, 3 - social. On a scale, the number of emergencies was: state level -2 , regional level -6 , local level -64 , object level -56 . As a result, 168 people were killed ( 40 of them were children) and 839 were injured (401 of them were children). [1].

One of the most important components of ensuring the effective execution of civil protection tasks is the proper professional training of personnel of civil protection units to perform their assigned tasks [1].

Despite the considerable amount of scientific research on the professional training of personnel for rescue units, the issue of training skilled workers (personnel of operational subdivisions) in the Operative and Rescue Service of Civil Protection is insufficiently studied [6]. 
Pedagogical aspects of the problem of professional training of specialists are revealed in the works N. Abashkina, R. Hurevych, I. Ziaziun, V. Kremen, A. Kuzminskyi, A. Lihotskyi, L. Lukianova, N. Nychkalo, L. Romanyshyna, M. Sysoieva, S. Smetanskyi, V. Yahupov and other scientists.

The process of professional preparation for performing professional actions in conditions of influence of factors of extreme situations was investigated by O. Aleksandrov, V. Ashmarin, A. Bolshakova, L. Hontarenko, O. Didenko, M. Diachenko, I. Zhdanov, L. Kandybovych, M. Koziar, O. Kokun, M. Korolchuk, D. Liebiediev, V. Lefterov, S. Myronets, V. Miroshnichenko, O. Okhremenko, V. Plisko, S. Poltorak, V. Sadkovyi, O. Sklen, O. Sobchenko, S. Yavorskyi and other scientists.

A significant contribution to improving the professional training process has been made by such scientists: V. Arkhypenko, O. Bykova, V. But, V. Buzko, V. Varenyk, N. Vovchasta, V. Hora, L. Didukh, A. Demchenko, O. Diachkova, O. Ivashchenko, L. Ishychkina, M. Koval, I. Koval, M. Koziar, M. Kryshtal, M. Kusii, L. Mokhnar, Yu. Nenko, O. Parubok, K. Pasynchuk, O. Povstyn, V. Rotar, V. Solntsev, M. Severin, Yu. Taimasov, T. Tkachenko, O. Uzun, M. Shkarabura and other scientists.

Research results. In order to develop the professional knowledge, skills and abilities of the personnel, to maintain a high level of prompt readiness of regular guards, there exists a continuous, year-round system of independent and professional training in the structural units of Operative and Rescue Service of Civil Protection of Ukraine. [3,6].

Independent training [4] is a continuous process of independent work of personnel in acquiring, deepening and updating the knowledge, skills and abilities necessary for the successful fulfillment of their functional duties, defined by the job descriptions in certain positions.

In-service training is a system of activities aimed at securing, updating and acquiring the necessary knowledge, skills, and professional qualities with the staff to ensure successful completion of assigned tasks [5].

The main types of classes in the system of training are: lecture; seminar; practice session; tactical-special training; check-up class.

In addition, the personnel of the units have:

- working out of the standards for special physical training in the academic period in excess of the educational plan established in the calendar plan, as well as in the summer period of the year;

- independent training of officials who have an admission to the independent performance of the duties of fire extinguisher;

- independent training of substitute radio telephonists;

- development of documents of rapid response (operational plans and fire fighting cards);

- night test practical exercises with the development of tactical tasks;

- analysis of operative actions for extinguishing fires and elimination of consequences of emergencies and dangerous events.

Practical classes are conducted at sports fields, obstacle course, training grounds, workplaces, during which the knowledge, skills to perform professional tasks independently using modern equipment, mechanisms and equipment are formed and developed.

Practical training of exercises (exercises and standards for special physical training) is carried out individually and in the unit (department, subdivision).

Operational deployment standards are compulsory with the work of drivers using special vehicles and the supply of extinguishing agents.

Practical classes can be combined with practical development of operational documents of response, study of the characteristics of the objects of the service area, provision of services.

Elaboration and correction of documents of the operative response (plans, cards) are organized during conducting lessons on departure to the object so that the whole staff of the of the unit knows the operational-tactical features of the most important and potentially dangerous objects located in the service area.

During tactical study of the area of service and facilities the staff studies the features of organization operational firefighting and emergency rescue in the area of firefighting station and explosion risk and the most important sites located in the area of service and other areas served by the firefighting station for firefighting and emergency response at higher numbers call.

In solving tactical tasks, personnel work out in the complex of action and interaction as a part of the department, subdivision of fire fighting and emergency management at this facility in a specific environment. This form of training provides an opportunity to improve the practical skills of the 
personnel in specific conditions, as well as the knowledge and skills of commanders of divisions and chiefs of guard to organize the elimination of the accident and to carry out the management of subordinates in an operational environment.

Night test practical exercises with the training of tactical tasks are conducted once a month by the persons designated by the head of the body and civil protection unit, with each duty guard, department.

For the purpose of studying the peculiarities of occurrence and free development of fire, assessment of the fidelity of decisions made by the fire extinguisher (head of emergency elimination) and the quality of their implementation by the personnel of the unit, assessment of the quality of preventive work on the site, fires and other emergencies are considered by all personnel within 10 days.

In the structural units of Operative and Rescue Service of Civil Protection of Ukraine, tactical and construction classes are practiced, in which the personnel of the guards study and work out actions during the emergency investigation, rescue of people, evacuation of material assets and liquidation of the accident at objects in different conditions. The purpose of tactical and structural training is the formation and development of personnel activity, courage, determination, perseverance, ingenuity, working out the interaction between the operational units in the branches and guards in different conditions of the operational environment.

In the course of tactical-special exercises the tactical skills of the command staff and the skills of the operational staff of the units to extinguish large and complex fires and the elimination of emergencies, which involve a large number of forces and means of civil protection improve simultaneously.

Special competitions of professional skill are held in order to stimulate personnel in the constant improvement of skills and competences by the bodies and units of civil protection.

Conclusions. The article describes the practical component of the professional training of the personnel of the operational calculations of the rescue units directly in the units. Types of practical training of rescuers in the divisions of the Operative and Rescue Service of Civil Protection of Ukraine are characterized: practical training of exercises (exercises and norms on special physical training), working out and adjustment of documents of operative response (plans, cards), operative-tactical study of area activities, solving tactical problems, night test practical exercises with the development of tactical tasks, fire and emergency management, tactical and construction classes tactical exercises.

At the same time, there is a contradiction between the increased level of requirements for the preparedness of rescuers in modern conditions and the traditional system of their professional training, which does not take into account changes in the extension and complication of professional tasks, which is a prospect for further scientific exploration.

\section{REFERENCES}

1. Analitychnyi ohliad stanu tekhnohennoi ta pryrodnoi bezpeky v Ukraini. - Kyiv: Ukrainskyi naukovo-doslidnyi instytut tsyvilnoho zakhystu [Elektronnyi resurs]. URL: http://undicz.dsns.gov.ua/ua/Analitichniy-oglyad-stanutehnogennoyi-ta-prirodnoyi-bezpeki-v-Ukrayini.html

2. Kodeks tsyvilnoho zakhystu Ukrainy № 5403-VI. (2012). URL: https://zakon.rada.gov.ua/laws/show/5403-17

3. Koziar M. M. Teoretychni ta metodychni zasady profesiinoi pidhotovky osobovoho skladu pidrozdiliv z nadzvychainykh sytuatsii : avtoref. dys. ... d-ra ped. nauk : 13.00.04. Vinnytsia, 2005. $37 \mathrm{~s}$.

4. Nakaz Ministerstva Ukrainy z pytan nadzvychainykh sytuatsii ta u spravakh zakhystu naselennia vid naslidkiv Chornobylskoi katastrofy: Pro zatverdzhennia Nastanovy z orhanizatsii profesiinoi pidhotovky ta pisliadyplomnoi osvity osib riadovoho i nachalnytskoho skladu orhaniv i pidrozdiliv tsyvilnoho zakhystu № 444. (2009). URL: www.dsns.gov.ua/files/2017/1/19/osv/444.doc

5. Nakaz Ministerstva vnutrishnikh sprav Ukrainy: Pro zatverdzhennia Poriadku orhanizatsii sluzhbovoi pidhotovky osib riadovoho i nachalnytskoho skladu sluzhby tsyvilnoho zakhystu № 511. (2017). URL: https://zakon.rada.gov.ua/laws/show/z0835-17

6. Pokaliuk V. M. (2020) Pidhotovka Osobovoho Skladu Operatyvnykh Rozrakhunkiv Riatuvalnykh Chastyn v Strukturnykh Pidrozdilakh Operatyvno-Riatuvalnoi Sluzhby Tsyvilnoho Zakhystu Ukrainy. International Journal of Innovative Technologies in Social Science. 2(23). doi:10.31435/rsglobal_ijitss/28022020/6947

7. Nyczkalo N. Ukraińska oświata zawodowa: doświadczenie, nowe wyzwania i poszukiwania.//PolskoUkrainski rocznik naukowy// Edukacja zawodowa i ustawiczna// Warszawa: wydawnictwo Akademii Pedagogiki Spevjalnej, 2016. - s. 125-140 